\title{
THE LANGUAGE AND LITERATURE OF MALTA: A SYNTHESIS OF SEMITIC AND LATIN ELEMENTS
}

\author{
OLIVER FRIGGIERI \\ University of Malta \\ Department of Maltese, Faculty of Arts, University of Malta, Msida, Malta \\ e-mail: oliver.friggieri@um.edu.mt
}

The history of Malta is a sequence of experiences which exposed the country to various cultures and consequently contributed towards its growth into a nation not only claiming to be distinct, but also having full awareness of its own identity. The Semitic character of its language and the Latinity of its culture have both contributed towards the complex formation of a unique country. This paper seeks to outline the development of the Maltese language as a medium through which Malta could best express itself and construct its own literature. Located midway between two continents, Malta's geographical position is thus coherently reflected in this duality.

Key words: Malta, Semitic, Latin, language, literature, romanticism.

A history of Maltese culture may be said to reflect in various ways the history of the whole community. Since much more than in the case of larger countries, Malta could never do without foreign contacts, necessarily leading to a complex process of influences. Such a history, be it political, social or cultural, is bound to assume a comparative character. Islands can be understood only as entities within a much larger context surrounding them. What are euphemistically called foreign contacts were nothing less than foreign occupations. The conditions which characterise and modify the process of, say, a political history of subordination, may boil down to be the real causes of analogous conditions in the cultural field. ${ }^{1}$

Conflicts of various natures did come to the fore throughout Maltese history. In the case of literary culture, the basic conflictuality seems to be linguistic and not necessarily cultural or psychological. The roots of the dualism to be discussed here

${ }^{1}$ Within these parametres a systematic definition of Malta's complex cultural identity is provided in numerous works which illustrate the duality typical of Malta as mainly due to the Semitic-Latin nature of the Maltese language (cf. Cortis 1989; Frendo 1972; Strickland 1921; Fiorini-Mallia Milanes 1991). 
are embedded in the soil of political experience: there were the foreign rulers and the natives, the ruled ones. Within the category of the ruled, social stratification manifested itself in linguistic diversity. The so-called uneducated class only knew Maltese, the native tongue, whereas the others could immediately distinguish between the language of culture, traditionally Italian, and the local dialect (Zammit 1988, pp. 163-211).

Considering the two major languages which assumed the role of primary media for literary expression, one has to start by distinguishing between Italian and Maltese. The relationship between Italian and Maltese had been looked at, up to a few years ago, as controversial, or worse still, as the unhappy intercourse between a Latin culture, the presence of which in the island goes back many centuries, and a Semitic one, characterised mainly by the basic Arabic structure of the popular language which, owing to the island's uninterrupted contacts with the outer world, adopted a Romance superstructure. One has to distinguish the nature of the apparently contradictory Italian-Maltese relationship from a purely linguistic viewpoint. After getting a clear perspective of the 'Language Question', which constituted one of the major political preoccupations between 1880 and 1939, one may proceed to deal with the significance of the concept of duality in the Maltese view of life. The Semitic-Latin synthesis, most evident in the composition of the Maltese language, may explain much of what being Maltese uniquely stands for. ${ }^{2}$

The Arab domination (870-1090) did not cause a complete detachment from Western culture. During the Norman rule initated in 1090, a period during which almost all of Sicily faced the same situation, there were Maltese Arabs who took an active part in the artistic revival which King Roger inaugurated on the nearby island (Vella 1974, p. 81). Up to about 1200 Arabic continued to predominate as the cultural language of Malta. Arabic epitaphs went on being written for about a century following the arrival of Count Roger. In 1249 the Moslems were forced to leave the island (Amari 1880, p. 213), and as Arabic was going through the process of transforming itself into the new local speech habit, it found itself open to new influences. The Normans introduced Sicilian, and from then on Maltese was exposed to enormous phonetic and lexical influences of a different nature. Joseph Aquilina (1911-1997), the first holder of the Chair of Maltese and Oriental Languages (1937-1976) at the University of Malta, resolves the question of cultural and linguistic continuity on the island as follows:

"When the Arabs conquered Malta they found a native community, and a Christian church that must have had its own non-Arabic language. What happened to the language spoken by the native Maltese? The answer is: precisely what happened to the indigenous languages of North Africa and Egypt. Another question: how do we explain that the Arabs did not likewise replace Sicilian by Arabic? That is really a question of numbers. There were more Sicilians than Arabs - many more as a matter

\footnotetext{
${ }^{2}$ This fusion is the essential motive of Oliver Friggieri's Storia della letteratura maltese (Friggieri 1986a).
} 
of fact: and Sicily being a much larger island was in a better position to safeguard her linguistic independence." (Aquilina 1961, p. 46) ${ }^{3}$

\section{A Historical Dualism}

The linguistic-cultural dualism of Malta is the most secure point of reference in any effort to define the island. The oldest known language of the island has a Semitic origin and has a long oral tradition which made it survive within the community which had no ability to write. The written tradition, on the other hand, secures a place for it in the Italian tradition (cf. Friggieri 1978, pp. 7-32). The earlier tradition is considered popular, unrefined, probably 'inferior', completely detached from the sources of culture as defined traditionally in a strict sense. It is the expression of a community which makes use of words of Arabic origin for daily use. It guarantees expression and communication within its limited circle. The second tradition is deemed sophisticated, tied to the centres of power and of the dominant culture, both legal and ecclesiastical. The conflict between the spoken tradition of Arabic origin and the written tradition of Latin origin is fundamental in understanding the socio-cultural experience of the Maltese, at least since the Arab period, when Malta's Mediterranean character started to get closer to European culture, thus causing new modes of development and adaptation, as well as direct confrontations, frequently implied and subtle. ${ }^{4}$

The dualism concerning Arabic and Latin heritage, equivalent to a conflict between the ruled and the ruler, largely explains why the recognition of Maltese could only occur when Europe was going through a 'romantic revival', the discovery of nationalism as an end in itself as well as a means to an end. Within this context, the hitherto neglected Arabic dialect, deprived of any sort of recognition, even lacking a standardised alphabetical system enabling it to be properly read and written, started to attract the attention of both Maltese and foreign scholars, all interested in normalising the alphabet, reconstructing its vast lexical stock, and writing it down elegantly, always in a manner which could put on show its syntactic and semantic resourcefulness. ${ }^{5}$ The time was ripe for literature in Maltese to further explore and develop new thematic and formal territories.

${ }^{3}$ Aquilina partly bases his conclusions on G. Picciotto's (1959) article.

${ }^{4}$ Henry Frendo dwells at length on Malta's colonial experience (cf. Frendo 1989 and 1999).

${ }^{5}$ The normalisation of the Maltese orthography is one of the most evident and substantial manifestations of the fusion of Arabic and Latin elements into one unique whole throughout the cultural history of Malta. Thus, for example, the Romance word risposta (answer) is written according to the same Maltese alphabet as the Semitic equivalent twegiba. Joseph Aquilina describes the various orthographic systems, formulated since the early writings of Gian Francesco Bonamico (16391680 ) up to 1934, when the system proposed by the Ghaqda tal-Kittieba tal-Malti (the Society of Writers in Maltese, founded in 1920 with the specific aim of providing a standardised orthographic system) was considered to have reached the required scientific character. He strongly distinguishes between the Romanists and the Arabists: "The Arabists were those who, basing themselves on the fact that Maltese is a Semitic language, akin to Arabic or, as some others wrongly believed, to Hebrew, favoured the use of the Arabic alphabet" (Aquilina 1961, p. 81). 
The European romantic movement was to cause an analogous awareness within the Maltese community. By the end of the first half of the 19th century, the island, a British colony directly exposed to the traditional culture of neighbouring Italy, reached the stage when it had to understand that political emancipation could be mainly attained through culture, and that culture could reach its aims whenever people are proud of their linguistic heritage. Such patriotic statements were typical of the era. Malta was mature enough to strike a middle course between the exclusive use of either English or Italian, and recognised the fact that only Maltese, an offshoot of Arabic, namely a non-European phenomenon, could be proved to be the oldest and the only national language of Malta. ${ }^{6}$

Set against this background, the revival of Maltese and the gradual development of Maltese literature in Maltese, as opposed to the previous tradition of Maltese literature in Italian, can be fully perceived as direct results of the application of the European romantic vision to the situation prevailing in Malta. Such a task, in typical Risorgimento style, could be best achieved by politically oriented writers. As they expressed themselves in Italian, they gradually adhered to the principle that nationhood and language are profoundly related to each other, thus producing popular unanimity. Such belief is the cause of various Maltese men of letters finally opting either for going on writing in Italian and now also in Maltese, or dedicating themselves entirely to writing in Maltese.

\section{Cantilena: A 15th-Century Arabo-Italian Document in Maltese}

Maltese literature in Maltese started to flourish on a really wide scale during the 19th century. Romanticism, a view of life as well as a way of living, was founded on the belief that distinctive individualism, both singular and collective, was the supreme virtue. Such a principle utterly favoured the discovery and cultivation of Maltese for creative as well as for practical purposes. One of the earlier and more refined poets of the initial period, Gan Anton Vassallo (1817-1868), fully exemplifies the whole cultural compromise being outlined here as typical of Maltese identity. ${ }^{7}$ Vassallo, a lawyer

${ }^{6}$ The Language Question, the conflict between two movements known as pro-Italian and pro-British, and the problem concerning the relationship between national identity, the native language and ethnicity are all considered by Geoffrey Hull as aspects of one unique phenomenon, namely, the cause-effect relationship between cultural traditions and political action (cf. Hull 1993).

${ }_{7}^{7}$ Gan Anton Vassallo was the first important Maltese author who sought to reconcile the characteristics of the esteemed Italian tradition of the island, and those of the emerging one expressed in a dialect hitherto not utilised for works claiming literary value. His romantic belief in literature as a democratic experience is summarised in Hrejjef $u$ Cajt bil-Malti (Vassallo 1895). Writing in Italian, he proclaims his social duty as a democratic poet, implying that he was bound to prefer Maltese to Italian:

Del popolo io son, ed a lui pegno

D'amore do nel poco dove arriva

La penna cui mi die' povero ingegno,

Onde fatti e costumi gli descriva. 
by profession, namely a member of the professional class which adopted the exclusive use of Italian at both the spoken and the written levels, was himself a professor of Italian at the University of Malta. His strong democratic beliefs made him aware that it was only through Maltese that he could make himself understood by the general public. In writing poetry of a popular nature he managed to convey a message far transcending the confines of a certain type of literature which is only academically relevant. $^{8}$

This stanza from his most well known poem, Tifhira lil Malta (In Praise of Malta) includes the main intercontinental, intercultural elements involved in this typically Maltese approach to the modern, democratic use of language:

Int sabiha, oh Malta taghna!

Mhux ghax Malti nfahhrek jien;

Issemmik id-dinja kollha,

Maghruf ġmielek kullimkien.

You are beautiful, oh Malta of ours,

It is not because I am Maltese that I praise you;

The whole world speaks about you,

Your charm is known everywhere.

With the exception of $o h$, all the words are derived from Arabic. The formal components, such as the stanza, the rhyme scheme, the syntactic structure, the imagery, are all literary features he derived from his knowledge of Italian culture. The spontaneity with which he unifies the component parts of two distinct cultures had been a main challenge facing early poets in their efforts to use an exclusively Arabic vocabulary to come forth with a typically Italian, eventually Maltese, quatrain. The example chosen here involves the poetic form - the quatrain, made up of four octosyllabic lines with alternate ryhme between the second and the fourth line - but the same conclusions can be reached in analysing any other genre. This complex tradition, a dualistic composition (Arabic, Italian) producing an autonomous form of expression (Maltese), goes back at least to the early 17th century, involving the same equally functional Arabo-Italian composition. The more significant poets and novelists

His poetry may be said to participate in three typical sources of inspiration which then, if considered as a whole, can be said to constitute the essential definition of European romanticism. Although he firmly believes that Maltese culture is essentially European, he is equally loyal to the Arabic nature of the language spoken by the people. He succeeds in striking a middle course between the 'Purists' who wanted to exclude all non-Semitic words, and the 'Italianists' who sought to italianise Maltese in all possible manners, namely, etymology, vocabulary, phraseology, syntax. His interpretation of Maltese identity in relation to language and culture is best expressed in his books Moghdija taz-Zmien fil-Lsien Malti (1843), Prolusione al corso di letteratura italiana nella R. Universita' degli Studi (1864) and Hrejjef u Cajt bil-Malti (1895).

${ }^{8}$ Guze' Cassar-Pullicino identifies in Gan Anton Vassallo a scholar whose romantic spirit naturally induced him to apply the principle that writers should be socially relevant and contribute towards the betterment of all, especially of the working class. Vassallo, though being a Professor of Italian at the University of Malta, rightly understood that he could adhere to the romantic spirit of the era only if he made full use of Maltese (cf. Cassar-Pullicino 1964, pp. 73-79). 
of the initial period adhering to this trend are: Gan Frangisk Bonamico (1639-1680), Gioacchino Navarro (1748-1813), Patri Fidiel (c. 1762-1824), Frangisku Saverju Baldacchino (1774-1860), Ludovik Mifsud Tommasi (1796-1879), Luigi Rosato (1795-1872), Indri Schembri (1805-1872), Salvatore Cumbo (1810-1877), Annibale Preca (1832-1901), Salvatore Frendo de Mannarino (1845-1918), Guze' Muscat Azzopardi (1853-1927) and Anton Muscat Fenech (1854-1910). ${ }^{9}$

The most important document in the whole tradition of writing in Maltese which can be evaluated in the light of this fusion of Semitic and Italian cultures into one distinct end-result is the mid-15th-century poem Cantilena, by Pietru Caxaro. ${ }^{10}$ The existence of such a text does not prove in any way that Maltese was written at that time. Centuries still had to pass for the Arabic dialect spoken by the community to have a standardised alphabet and to be considered worthy of any academic, literary and political consideration. Caxaro could have resorted to Maltese just to assess how could Arabic be transcribed. As a cultured person Caxaro must have been aware that the poetic form prevailing in Italian literature was the allegory, and his Cantilena is actually a narrative with a double meaning. It gives room for a literal as well as for a metaphorical rendering, and is faithfully inspired by Christ's parable about a man constructing a house (Mt 7, 2-27; Lq 6, 4-49).

Apart from the fact that Maltese poetry is born with the employment of a language of Arabic origin according to European forms of literary expression, thus remaining within the traditional limits, it should also be noted that the earliest poem in Maltese has a Christian substratum, and is expressed in the form of a parable, a genre largely depending on allegory. The Oriental character of the two makes Cantilena more complex in its formation, since it all conduces to the conclusion that in Malta culture in general and literature in particular could only develop according to the

\footnotetext{
${ }^{9}$ These poets were all the product of an environment composed of two main factors: high culture is expressible in Italian, whereas popular culture is efficiently expressed in the native tongue. The gap between the two extremes could be bridged through a compromise involving both cultures. Whilst making full use of their natural adherence to the Italian literary tradition, they eventually discovered their real self through the proper handling of Maltese. Historical continuity is adhered to, the really new factor being the full adoperation of 'Malti safi', namely the preference of Maltese words of Semitic origin to words of any other origin. An essential collection of their poetry is included in Aquilina (1948), and in Friggieri (1996).

${ }^{10}$ Pietro Caxaro died in 1485. He lived in Mdina and Brandan De Caxaro, a relative of his, described him as a 'philosopher, poet and orator'. He acted at least twice as judge between 1441 and 1475, as well as judge of the Commune between 1461 and 1483 (cf. Wettinger-Fsadni 1968, pp. 15-22). The dating of the Cantilena makes it possible for the earliest writing in Maltese to be collocated within the same period of time during which the oldest Italian manuscripts retained in Malta were registered (cf. ibid., p. 32). It is important to note that notwithstanding his high social status, Caxaro was attracted at least once by the idea of composing a poem in Maltese. This decision implied having to create an alphabet for an unwritten Arabic dialect, adhering to the metrical system practised in local versified compositions, choosing words deemed to sound sublime in terms of content and pleasant in terms of form. The Maltese literary practice of resorting almost exclusively to Maltese words of Arabic origin, whichever the genre, has its origin in Caxaro's poem. Even Modernism still adheres to this preference. Such evolution is best manifested in anthologies of a historical, or chronological, orientation.
} 
island's main determining factors: its geographical position midway between Southern Europe and Northern Africa, the Christian tradition, the Oriental nature of the popular speech habit, the adoption of Italian as the language of administation. Cantilena deserves to be carefully scrutinised in all formal and thematic respects because (a) it represents a poem in a type of Maltese which is still close to Arabic, its original source from several hundreds of years before; (b) it identifies the condition through which the Maltese language could eventually start to be written down as an Arabic document within a European context; (c) it manifests the early fusion of Arabic vocabulary and Italian literary device.

Xidew il-qada, ja girieni, tale nhadditkom,

Ma nsab fil-weri u la nsab f'ghomorkom

Qalb m'ghandha hakem, sultan u la mula

Bir imghammiq irmietni, b'turgien muhsula,

Fejn, hajran ghall-harqa, ninzel f'tarag minzel

Nitla' u nerga' ninzel dejjem fil-bahar il-gholi.

Waqghet hi, imrammti, l'ili zmien nibni,

Ma htatlix mghallmin, 'mma qataghli tafal merhi;

Fejn tmajt insib il-gebel sibt tafal merhi;

Waqghet hi, imrammti.

Waqghet hi, imrammti, nizzlet hi s-sisien;

Ma htatlix 1-imghallmin, 'mma qatghetli l-gebel;

Fejn tmajt insib il-gebel sibt tafal merhi

Waqghet hi, imrammti, l'ili zmien nibni.

U hekk waqghet hi, imrammti! W erga' ibniha!

Biddillha inti l-imkien illi jewtiha

Min ibiddel 1-imkien ibiddel il-vintura;

Ghaliex l-iradi ghal kull xiber sura:

Hemm art bajda, w hemm art sewda u hamra.

Aktar minn hedawn hemm trid minnha tmarra.

O my neighbours, come, let me tell you;

It has never been found in the past and neither in your lifetime.

An ungoverned, kingless, and lordless heart

Has thrown me into a deep well with steps of my downfall:

I rise and fall always in the high sea.

It has collapsed, my house which I've long been building.

The workmen are not to blame, but the loose clay gave way.

Where I had hoped to find rock I found loose clay:

It has collapsed, my house.

It has collapsed, my house has pushed down the foundations.

The workmen are not to blame, but the rock gave way:

Where I had hoped to find rock I found loose clay;

It has collapsed, my house which I've long been building

And that's how my house collapsed! And build it up again! 
Change for it the place that harms it;

He who changes the place changes his fortune;

For each stretch of land has its characteristic:

There is white land and there is black and red land;

More than this you need from its fruit.

\section{(translation by Charles Briffa)}

The most striking aspect of Caxaro's adherence to the Italian literary tradition of his era is the choice of the hendecasyllabic line, a metrical line made up of eleven syllables, the tenth one of which is always accented, whereas other accented syllables could be the first, the fourth and the eight, or the fifth and the seventh. Greek and Latin poets frequently chose this metre. In choosing the hendecasyllable Caxaro must have been aware that by the time he wrote the poem, major Italian poets, like Dante and Petrarch, had already chosen this metre for their works, especially those written according to established formal chacteristics, such as terza rima, ottava rima and the sonnet. ${ }^{11}$ They must have believed that this verse was the best one with which they could prove that Italian was sufficienty resourceful to be compared with Latin. The Italian-Latin paradigm is parallel to the one prevailing in Malta, namely MalteseItalian. The Cantilena has seven lines which are perfect hendecasyllables, namely lines $2,3,7,14,18,19,20$. There are several slightly imperfect hendecasyllables: lines 4, 9, 13 (the third syllable is superfluous), lines 11 and 17 (the seventh syllable is superfluous), line 16 (the fifth syllable is superfluous). Line 9, repeated as line 13, can be interpreted as a composite verse made up of an octosyllabic line (containing eight syllables) and a quinary (containing five syllables). All lines rigidly follow the main rule of Italian metre, namely the retention of a fixed accent on the penultimate syllable. Whereas the poem is made up of hendecasyllables, the tenth one is a seven feet line with the first syllable missing. ${ }^{12}$

Caxaro is consistently faithful to the classical use of the caesura, a pause within a line naturally required by the rhythm or by the syntactic flow of the words as they move ahead towards the end of the line. The use of the comma indicates such a break:

Xidew il-qada, ja girieni, tale nhadditkom.

O my neighbours, come let me tell you.

He also resorts to the use of 'rima baciata', thus producing a persistent sound scheme which further develops repetition. Other literary devices intended to produce insistence on the same sounds are the ritornello ('waqghet hi, imrammti!'), the choice

${ }^{11}$ The most important Italian works of the era establishing the prominence of the hendecasyllable are Vita Nuova, Rime, and Divina Commedia by Dante Alighieri (1265-1321) and Canzoniere by Francesco Petrarca (1304-1374).

${ }_{12}$ The metrical system of traditional Maltese poetry is identical to the one used by Italian poets. This is due to the fact that there is complete continuity between the older period in the history of Maltese poetry (written mainly in Italian) and the later period (characterised by the employment of Maltese with a specified literary ambition). All components of Maltese prosody are equivalent to those typical of the Italian tradition (cf. Friggieri 2010, pp. 464-470). 
of words with double consonants ('dejjem', 'biddillha', 'illi', 'ibiddel', 'hemm', 'minn', 'minnha', 'tmarra'), the avoidance of enjambment, and the way known metrical schemes are used to convey a plaintive tone throughout. These stylistic modes, introduced by Caxaro in the first half of the 15th century, have been retained since then by Maltese writers and form part of the essential technical apparatus of poetry in Maltese. It is not easy to determine to what extend this aspect implies reference to the qasida, a genre which, given some variations, is somehow adopted by Erin Serracino Inglott (1904-1983) and Mary Meilak (1905-1975).

\section{The Literary Tradition}

Considering the traditional presence of both languages in Malta, the first conclusion is that Maltese is prior to Italian as a spoken medium, whilst there is hardly any proof that Italian was ever adopted as the habitual speech medium by any local section of the population. Linguistic differences imply social distinction, but in cases like the one typical of small territories like Malta, the determining factor is power. Maltese has always been the speech habit of the subdued community, powerless in its own land and perhaps isolated from the outer world due to its language itself. The most important effect of such a condition is that scholars are still undecided as to what was the language of the Maltese prior to the arrival of the Arabs, a prominent historical event marking the introduction of Arabic into the island, and eventually the gradual transformation of Arabic into Maltese, a dialect gradually grown into a proper language with various distinctive features.

The fact that the Arabs conquered Malta in 870 A.D. and thus laid the foundations for the language known as Maltese has been the subject of great debates amongst politicians and scholars for several decades during which the Language Question evolved into a thorough analysis of what it meant to be Maltese. The language started to be considered as unique for being a Semitic tongue written in the Latin script, as well as for being the sole national language of an island standing midway between two continents, and being the complex end product of two distinct cultures fused into one whole.

With the Norman Conquest in 1090 A.D. the language of the island started to find itself open to extra-Arabic influences, a process which has widened the lexical stock and the syntactic patterns, and which is still active nowadays, especially due to the overwhelming exposure to English, itself an official language of Malta beside Maltese.

When Maltese started to be written on a significant scale in the 17 th century (other instances are being here purposely omitted since they are rather rare and sporadic), and then on a much wider popular level in the 18th and the 19th centuries, Italian had already established itself as the only and unquestionable cultural language of the island, and had a respectable literary tradition of its own. One of the earlier local 
documents in Italian dates back to $1409 .{ }^{13}$ Maltese men of letters developed an uninterrupted local "Italian" literary movement which went on up to the Second World War period, whereas Maltese as a literary idiom started to prominently co-exist in the first half of the 19th century, and reached a respectable climax in its last decades (cf. Briffa 2014, passim).

This deposit of "Italian" literary output throughout the centuries, a considerable section of which is still in manuscript form at the National Library of Malta, is the work of both Maltese and foreign writers who happened to spend a period of time or settled in the island.

The Risorgimento period, affecting Malta mainly between 1804 and 1860, saw the emergence of two opposing linguistic movements, one favouring the complete Italianisation of culture and the other cultivating Maltese to the point of rendering it 'pure', namely making it acquire once again its original characteristics, mainly by eliminating all loan (namely, non-Arabic) words, and by deriving words through the three-consonantal root system. This current of thought and writing, known as 'Malti safi' and 'Purizmu' ('Pure Maltese' and 'Purism'), strongly favoured the revival of archaisms. The main method through which modern Maltese could introduce new words from itself was making full use of the three-consonantal system typical of Arabic. Many Maltese poets and novelists strongly adhered to this view, forming words from the original verb also to show that the language was self-sufficient. Thus words of non-Arabic origin could be eliminated and substituted by the new ones. This attitude was adopted mainly by Biblical translators, but it proved to be unpopular and was subsequently abandoned. It all implied that Maltese had lost its original, direct connection with its real source. Newly derived words like Ruh il-Qodos (Holy Spirit), maqdes (temple, a noun derived from the three radicals Q-D-S), midbah (altar, a noun from D-B-H) readily come to mind, but were never adopted by the native speakers. Ruh il-Qodos is the standard term in classical Arabic for the concept of the Holy Spirit (cf. Myers 1987, p. 496). ${ }^{14}$

The purist movement, however, was not solely linguistic, since it involved questions regarding the ethnic origin of the Maltese. Ethnic identity was equated with the origin of one's own language. Midway between texts which gave an Italianised version of Maltese and texts which employed only words of Semitic origin, there are works which sought a compromise made up of the use of Semitic words all placed according to a word order, actually a whole syntactic system, typical of Latin. Such is Anton Manwel Caruana's novel Inez Farrug (1889). Caruana is a complete purist in the exclusive choice of Maltese words of Arabic origin, and a classicist in the adoption of a Latin word order for syntax.

${ }^{13}$ The document is held at the Malta Cathedral Archives, ms. A, ff. 171-176, published by Alfred Mifsud (1918, pp. 243-248). Cf. also Mifsud (1917, pp. 39-40).

${ }^{14}$ The Maltese term 'Ruh il-Qodos' has been coined by Peter Paul Saydon (1895-1971), an eminent Maltese Biblical scholar, as an alternative to the more popular 'Spirtu Santu', derived from Italian. He derived it directly from the Hebrew phrase 'Ruah qados' in his Il-Kotba Mqaddsa Maqlubin ghall-Malti (1929-1956). 
Thus, whilst Maltese has the historical priority at the level of the spoken language, Italian has the priority of being the almost exclusive written medium for socio-cultural affairs for the longest period. The native language had only to wait for the arrival of a new mentality which would integrate an unwritten, popular tradition with a written, academically respectable one. This situation could only lead to the complete fusion of two major cultures, the Arabic and the Latin, into one unique whole. The Maltese language is the most significant document related to such a phenomenon, but it is not the only one.

\section{Arabic Vocabulary, Italian Genre}

The best example of such a fusion of Arabic and Latin cultures can be immediately found through a close look at the lyrics of the national anthem of Malta, written in 1922 by Dun Karm Psaila (1871-1961), the national poet of Malta, who produced his works exclusively in Italian till reaching his early fourties, and who then, in 1912, ${ }^{15}$ was made aware he could also express himself in his own native tongue (cf. Friggieri 2014, pp. 35-36). He maintained all the components of his cultural identity, which were all essentially Italian, and went on writing without in any way interrupting his creative itinerary or going through an identity crisis. His Maltese, faithful to his rural origins, is basically Semitic in its vocabulary, whereas his syntactic patterns are not to any degree removed from those spoken and written at the popular level, and considered as standard Maltese. He favoured the revival of ancient Maltese words of Arabic origin, now falling into disuse, and believed poetry was the best medium for such a project. Although he did not risk reviving Semitic words to the point of not being understood, he managed to attain literary dignity, the so-called 'decorum' the vernacular needed to be considered worthy of recognition.

The following are the six lines constituting Malta's national anthem, as written by Dun Karm Psaila in 1922 (cf. Friggieri 2014, p. 61). All words are Arabic, but the metrical pattern is based on the hendecasyllabic line, the most esteemed rhythmical pattern of the whole Italian prosodic tradition:

Lil din 1-art helwa, 1-omm li tatna isimha, Hares, Mulej, kif dejjem Int harist:

Ftakar li lilha bl-ohla dawl libbist.

${ }^{15}$ Dun Karm Psaila, popularly known as Dun Karm, had written exclusively in Italian and never felt he should express himself in Maltese before reaching his early fourties. His attitude up to that stage in his literary life is typical of the Maltese writers who went on abiding by tradition which completely debarred Maltese from all cultural and official circles. This is an essential aspect of Joseph Aquilina's interpretation of the passage from Italian to Maltese of such writers (cf. Aquilina 1949, passim). The bilingualism of traditional Maltese writers is the most important proof that there is a cause-effect relationship between the earliest and the more recent phases in the history of literature in Malta (cf. Friggieri 1978, passim). 
Aghti, kbir Alla, id-dehen lil min jahkimha, Rodd il-hniena lis-sid, sahha 'l-haddiem:

Seddaq il-ghaqda fil-Maltin u s-sliem.

This fair land, the mother that gave us her name,

Guard her, Lord, as You've always guarded her:

Remember that you have always draped her with the sweetest light.

Bestow, sovereign God, good judgement upon those who govern her, Grand mercy to the employers, strength to the workers:

Confirm the Maltese in unity and peace.

(translation by Charles Briffa)

The following is an Arabic version of the Maltese national anthem transcribed in the Latin alphabet. The similarity and closeness, lexical and phonological, are in all respects almost complete:

Hadihi l-'ard al-hulwa, al-'umm allati 'agh Tatna ismaha,

Uhrus ja Mawlaj kama da'iman harast;

Iftakir 'annaka 'ijjaha bi-'ahla Daw' 'albast.

'AghTija, Allah ja kabir, ad-dihn li-man jahkumuha,

Rudd al-hanan lis-sajjid, Sihha lil-ghamil:

Saddiq ghala wahdat il-Maltijin wa ghala s-salam.

(translation by Martin Zammit)

A highly significant and far-reaching conclusion may be drawn at this stage. A certain section of the community adopted two distinct languages, within the same inhabited territory, for different purposes. The spoken language was Semitic, whereas the written one was Romance. It is a distinction which may account for a certain degree of Malta's inherent inconsistency in assessing its own identity, which is still present nowadays when English in various respects assumed the role previously granted to Italian and made new inroads which, according to the criteria set and declared by UNESCO and the Council of Europe, occupy a territory exclusively reserved for the native tongue. Again, the dualism English-Maltese is not only linguistic, but also cultural, social and political. It is sufficiently safe, however, to presume that Maltese is still the common factor, the most efficient component in the definition of Malta as a distinct national entity.

If one seeks to identify the literary spirit of the Maltese throughout the centuries, one should also find it obvious to include the said Italian-oriented Maltese production, thus rendering it the first, or preliminary, phase of the whole spectrum, itself leading towards the modern emancipation of Maltese. This approach would seek to establish the social motives which debarred Maltese from all cultural manifestations, and why it was somehow dishonourable to use it. It is paradoxical as much as it is logical that the major literary figures in the history of Maltese are all so-called 'converts'; they were all authors well versed in Italian who at a certain point in their life 
discovered the sheer beauty and wealth of the native language, and eventually transformed it into a first-class literary medium.

Pietru Pawl Saydon (1895-1971), an eminent Biblical scholar of international repute, adamantly proved this point by dedicating no less than thirty years of his life to the translation of the whole Scripture from the original languages. Dun Karm (1871-1961), the national poet, openly declared that he wanted to show that Maltese was in no way inferior to either Italian or any other language. At times through direct translation, but mainly through the formation of new words by means of the activation of the three-consonantal Semitic system inherent in Maltese, he soon proved that what the language lacked was only a fine craftsman. He was to prove that a whole tradition went utterly wrong, and his texts now enjoy international esteem, especially where comparative studies are concerned. These are some of the most typical Maltese words of Semitic origin which Saydon formed from given roots in order to remain as faithful and as close as possible to the original texts: maqdes (temple), qsusija (priesthood), amar (command), ghamara (abode), bassar (prophet).

\section{The Romantic Solution}

The proper character of the Italian tradition in Malta, flourishing within a tiny community which had its own speech habit and traditions, can be best defined through a comparative analysis of the peninsula's literature and of the ways it influenced the island during a series of cultural epochs, such as Renaissance, Baroque, Illuminism and then Romanticism, by far the most important period so far as the formation of a national awareness in Malta is concerned. Romanticism, both Latin and Germanic, revalued the Illuminist concept of cultural diffusion and, while questioning the true significance and practicability of cosmopolitism, fostered the cult of national languages. This epoch, fundamentally based on the discovery of the sense of personal and national individuality, coincides with the first serious efforts towards the rediscovery of Maltese as one of the most ancient patrimonies of the new emerging nation. This is how Mikiel Anton Vassalli (1764-1829) calls it in 1796 in the important 'Discorso preliminare' introducing his own dictionary, Ktieb il-Kliem Malti, published by Antonio Fulgonio in Rome where he intended to demonstrate the Semitic character of Maltese, and to prove its antiquity. ${ }^{16}$

The historical dimension of a popular language featured very significantly in the concept of nationalism which European romanticism sought to form and preach. 19 th century mentality shaped the future of both language and literature in Malta in the times to come. One of the more important results of Vassalli's political and scholarly contributions is the embryonic development of a nationalistic way of thinking which centred around two basic aspects of romantic philosophy and aesthetics: (i) the

${ }^{16}$ A detailed analysis of Mikiel Anton Vassalli's complex personality, especially in the light of his perception of Malta as a combination of Semitic and Latin components (cf. Friggieri 1993, pp. $23-24)$. 
affirmation of the singular and collective identity (an experience emanating from the absolute confidence the romantics had in sentiment and passion, as opposed to the old and undisputed right enjoyed by the "goddess reason"); and (ii) the cultivation and diffusion of the national language as the most sacred component in the definition of the 'patria' and as the most effective justification for a dominated community's claiming to be a nation.

This new national belief promulgated by romantic Italy pervaded Malta during the period of the Risorgimento, namely during the first six decades of the 19th century, when writers, journalists and political rebels sought refuge on the island. ${ }^{17}$ Alongside their activity in favour of a united and independent homeland, these refugees engaged themselves in an analogous mission: that of inviting the Maltese themselves to fight for their own political and cultural rights against the British colonial domination. This started to give rise to an ever wider utilisation of the native language and to the gradual growth of an indigenous literature fully aware of the political, social and cultural rights of the community.

Different cultures, political attitudes, world visions and social customs crossed each other in 19th-century Malta and determined to a great extent the beliefs and modes of the people for a long time to come. What may superficially look like a mere historical background, buried in a relatively remote past, is actually the real foundation on which contemporary Malta is built. Languages were finally put in direct conflict, the past and the present transformed themselves into two ways of being, and colonialism and the concept of sovereignty became items of a new national agenda which demanded that a decision should be ultimately taken. Historical knowledge in Malta normally assumes the role of an arbiter between political parties in search of self-justification. This social trait may be due to the fact that the portrayal of Maltese, whether academic or popular, is also dual; words, phrases and syntactic structures are immediately conceived in terms of their being Semitic or Romance. This deep sense of duality has led to the consideration of speech and writing in terms of synonyms. These are two popular examples: answer - twegiba (Semitic) and risposta (Romance); leader - mexxej (Semitic) and kap (Romance).

\section{Language and Literature as Distinctive Features}

What is this multidimensional self made up of? The religion of the Maltese, originally Christian, namely Oriental (going back to about 60 A.D., as narrated in the Acts of the Apostles, 28, 1-10), has become Catholic, namely eminently Latin. The essential point underlying this interpretation is that the language of the Maltese is basically Semitic, dating back to the Arab occupation (870-1090), whereas the national culture

${ }^{17}$ Malta took an active part in the Italian Risorgimento not simply because it somehow evoked the Italian component of Maltese culture, but also because in the period 1804-1860 numerous liberal rebels sought refuge in Malta, as Britain, bound to retain its fame of a democratic state, turned a blind eye on what was happening on the island (cf. Mangion 1970). The list of the Italian liberal activists includes Francesco Crispi himself, a future Prime Minister of Italy (cf. Ardau 1939). 
is fundamentally European. Most of the terms used in liturgy are originally Semitic, whilst they form part of a Catholic ritual. The following are some of the more important Maltese words of Semitic derivation which are of primary importance in Christian ritual as expressed in Maltese: Alla (God), quddiesa (mass), tewba (penance), barka (blessing), qrar (confession), qdusija (sainthood), maghmudija (baptism), randan (lent).

Colonialism has left an indelible mark on all aspects of life in Malta, including the psychology of the average inhabitant, but political emancipation has provided the people with the full rights any people can dream of and strive for. The language is the most amazing example of how history in Malta is the final outcome of different components.

All this may drive home the point that the different cultures did not simply meet in Malta and leave their trace. They have also produced a specific psychological frame, an unquenchable thirst for new, hitherto unknown, tastes. All the different cultures which form the island's remote history - Phoenicians, Carthaginians, Romans, Arabs, Normans, British, just to mention the major ones - simultaneously denote submission to superior forces and the gradual formation of an indigenous identity through assimilation and adoption of foreign influences. Foreign dominations have also moulded the Maltese character, and the latter has proved itself strong enough to reshape whatever it had been subjected to. The literary spirit of the island can be summed up along these lines.

The main evidence of this phenomenon is to be found in the language. It is obviously the most characteristic feature of the island's national identity. It is primarily owing to the fact that Malta has got its own ancient language that it survived as a distinct nation.

A brief account of what is known as "The Language Question" may throw more light on the way different cultures flourished in Malta whilst giving room to the formation of a mature sense of modern national awareness.

\section{The Language Question}

Malta's insularity largely accounts for the development of an indigenous popular culture, segregated from the main foreign currents. Traditional mentality, being the complex result of a will to survive and to resist innovation, expressed complete faithfulness to the conditions of the simple life of the people, a predominantly rural and religious community taken up by preoccupations of a subdued rather than rebellious nature, concerned with the family rather than the nation. "The Language Question", a nationwide debate started towards the end of the 19th century and gaining momentum for about four more decades, departed from the need to define Malta's national language and developed into a quest for the real definition of being Maltese.

The geographical position and the political history of the island brought about a very close link with Italy. Traditional Maltese culture was mainly Italian. The Order of St. John (1530-1798) managed to transform the island into a cultural centre which 
eventually acquired its own respectable place within the Mediterranean spectrum. It was not surprising at all that Napoleon himself imposed his own power there in 1798. Owing to isolation, however, this multidimensional influx adopted the local 'original' aspects. The most significant feature of this experience is that Malta formed its own literary tradition written in Italian by the Maltese themselves. For centuries no intellectual doubted that one could be Maltese while writing in Italian and according to the Italian thematic and stylistic patterns. The local intelligentsia, spiritually belonging to an Italo-Maltese world transcending geographical demarcations, found its real historical self in forming an integral part of at least a big sector of the region. Boundaries were not considered to be territorial.

The concept of a local Maltese culture was not limited. It did not simply recognise the isolated product, created and considered without any relationship with the outer world. What we now term 'foreign' was only 'outer'. Therefore, isolation and insularity were not synonymous. Again, this is paradoxical: it was, as already stated, through insularity that the island managed to create for itself its own indigenous culture, but the source of initial inspiration was not isolation. Maltese writers expressing themselves in Italian were adequately conscious of what was happening in the nearby country. The major texts of Italian literature were very well known to them, and their educational apparatus relied to a great extent on them. On the other side of the fence there were the common people, speaking a traditionally downtrodden dialect, deprived of any official recognition, which up to the first decades of the 20th century still lacked a standardised orthographical system.

The language of the Maltese relied for several centuries on an almost exclusively oral tradition. It therefore had all the necessary qualities to be the only really native tongue of the Maltese; it was the oldest language known to exist on the island. It also had the inner strength of survival and automatically served for all the purposes of popular expression and communication. It was spoken by the whole community. Undignified though it seemed, it went on from strength to strength, becoming more resourceful and precise. It had a massive social function, and was the medium of religious expression, guaranteeing solidarity within the social class of its speakers. One day, when new trends of thought were to reach Malta from central Europe, this 'unworthy' speech medium was bound to attain the full recognition it warranted. The two distinct cultures, emblematic of two distinct social classes, were destined either to come in direct conflict with each other (as it happened at the political level) or to find a proper meeting point where the dignity of the written tradition could be assumed by the undignified unwritten one.

Both options were actually taken, and all this is being stated with hindsight and in the light of scientific research. In the early decades of the 20th century, however, things could not be, and were not, so simple and clear-cut.

The phenomenon can be described from another angle. The old Italian element of Maltese culture, particularly the literary one, is also a valid component of political psychology: the intelligentsia considered itself an integral part of the Mediterranean Sea which incorporated it in the Italian segment of the region. Therefore, the self-expression of Maltese writers in Italian was the self-expression of the Maltese as such, 
or better, of members of a community living in isolation on a small island which had fundamental points of reference that overcame introversion and provincialism.

It is against this background that the upheaval at the level of party politics can be safely understood. Up to the first decades of the 19th century the Maltese general perception was that (i) the country had an old cultural identity closely related to the presence of Latin culture and that the language of culture was Italian; (ii) the introduction of English constituted a serious threat to national identity, inasmuch as English was not only "a foreign language" but also the language of the coloniser. English could easily give a new advantage to the British ruler in the field of expression, by disrupting the normal expression and communication both of the leaders and of the cultured sector of the population.

The democratic awareness in favour of the people who knew only Maltese still had to reach maturity, as it did when writers who traditionally wrote in Italian discovered the strength of the Maltese tongue, and embarked on a wide programme of cultural diffusion through literary works or articles of a general nature written in an elegant Maltese style. Journalism is itself indicative of cross-cultures in action and reaction within a set environment.

The introduction of the foreign language (English) and the removal of the traditional local one (Italian) were considered another example of Britain's cultural plan for the whole empire. On the other hand, except in the minds of a few isolated individuals, it was too early for the Maltese language to be seen in its proper perspective of a famous and precious monument of antiquity, worthy of esteem, as it was described by Mikiel Anton Vassalli in 1796. Vassalli himself expressed his progressive ideas, inspired by the Illuministic and Romantic principles he inherited from France and Italy, in Italian. All the protagonists of the cultural development of Maltese, like Guze' Muscat Azzopardi, Dun Karm, Manwel Dimech and Ninu Cremona, wrote extensively in Italian. But things were bound to follow a different course as the whole world situation changed radically.

In the whole Language Question, the practical co-existence of Maltese, as opposed to Italian (the medium of traditional Maltese culture) and English (the medium of colonial Malta), was the difficult conclusion which Maltese society was not yet able to reach. Nonetheless, all this can be understood in its historical context. The emergence of Maltese as the national language and of both Maltese and English as the official languages finally solved a thorny problem which had surfaced for centuries. The Constitution of Independent Malta (1964) recognises and sanctions this reality. Maltese is taught in all schools and at all levels, and has its own Department at the University since the late 1930s. It is officially recognised as a medium of instruction and, together with English, is the official language of the University. Books in Maltese abound, covering a wide area of subjects, though most books are still literary. Maltese literature enjoys a prominent place at all levels of education. Both the Church and the political parties make full use of Maltese both written and spoken (cf. Marshall 1971, passim).

During the Language Question period the struggle had transformed itself into a confrontation between dignity and power, that is, between tradition and imperialism. 
The Ghaqda tal-Kittieba tal-Malti (Society of Maltese Writers), founded in 1920 with the specific aim of standardising the Maltese alphabet, sought to keep away from party politics as much as possible. However, political activity was the main, if not the only, opportunity for any efforts to be made in favour of the introduction of Maltese as the official new point of reference.

Since a language is not only a system of expression but also a complex manifestation of a whole way of life, the difference between the Latin, or better Mediterranean pattern of behaviour, and the English one renders the Language Question a psychological problem as well. An analysis of analogous movements in other countries may easily lead to similar conclusions.

\section{The Aftermath}

In the meantime, however, English could no longer be merely considered as the language of an empire, but steadily went on growing into an important vehicle for international communication. It was no longer possible to identify it solely with Britain, and it was necessary to adopt it as an instrument for relating with the outer world. In actual fact, since the post-war period it ended up with assuming the role previously played by Italian. The real innovation which occurred in this battle for cultural identification was the emergence of Maltese as the truly distinctive language of the country. Politicians and intellectuals now understood that it was mainly this traditionally dowtrodden language, inherited by word of mouth since the 9th century A.D., during the Arab period, that had kept the community united and nourished its sense of national individuality. The conflict between the two great cultural forces which exerted their full influence on Maltese sensibility, the Italian and the British, was solved through the recognition and the emancipation of the popular language, an ancient Arabic dialect grown into a full language, written in the Latin script, thus manifesting a positive relationship between two continents, as well as expressing the complex identity of the Maltese nation.

\section{Bibliography}

Amari, Michele (1880): Biblioteca arabo-sicula I. Torino-Roma, Loescher.

Aquilina, Guze' (ed.) (1948): II-Muza Maltija. Malta, Lux Press.

Aquilina, Guze' (ed.) (1964): Il-Muza Maltija. Malta, Dar ta' San Guzepp.

Aquilina, Joseph (1949): Studji Kritici Letterarji. Malta, Lux Press.

Aquilina, Joseph (1959): The Structure of Maltese. Malta, Royal University of Malta.

Aquilina, Joseph (1961): Papers in Maltese Linguistics. Malta, Royal University of Malta.

Ardau, Giovanni (1939): Francesco Crispi. Milano, Ceschina.

Briffa, Charles (ed.) (2014): This Fair Land. London, Francis Boutle Publishers.

Brincat, Joseph M. (2011): Maltese and Other Languages. Malta, Midsea Books.

Cardona, Guze' (1972): Dun Karm - Hajtu u Hidmietu. Malta, Klabb Kotba Maltin.

Cassar-Pullicino, Guze' (1962): Kitba u Kittieba tal-Malti I. Malta, Universita' ta' Malta.

Cassar-Pullicino, Guze' (1964): Kitba u Kittieba tal-Malti II-III. Malta, Universita' ta' Malta.

Acta Orient. Hung. 69, 2016 
Cini, Antonio (1903): Origine e progresso della lingua italiana in Malta ossia la lingua nazionale dei maltesi. Catania, G. Russo.

Cortis, Tony (ed.) (1989): L-Identita' Kulturali ta' Malta. Malta, Dipartiment tal-Informazzjoni.

Cremona, Ninu (1934): X'Inhu l-Malti Safi. Malta, Empire Press.

Fiorentini, Bianca (1966): Malta rifugio di esuli e focolare ardente di cospirazione durante il Risorgimento italiano. Malta, Casa San Giuseppe.

Fiorini, Stanley-Mallia Milanes, Victor (eds) (1991): Malta: a Case Study in International Cross Currents. Malta, Malta University Publications.

Frendo, Henry (1970): Ir-Rivoluzzjoni Maltija tal-1919. Malta, Empire Press.

Frendo, Henry (1971): Lejn Tnissil ta' Nazzjon. Malta, Klabb Kotba Maltin.

Frendo, Henry (1972): Birth Pangs of a Nation: Manwel Dimech's Malta. Malta, Mediterranean Publication.

Frendo, Henry (1989): Malta's Quest for Independence. Valletta, Valletta Publishing.

Frendo, Henry (1999): The Origins of Maltese Statehood. Malta, The Author.

Friggieri, Oliver (1978): La cultura italiana a Malta. Firenze, Leo S. Olschi.

Friggieri, Oliver (1980): Dun Karm - il-Bniedem fil-Poeta. Malta, Klabb Kotba Maltin.

Friggieri, Oliver (1986a): Storia della letteratura maltese. Edizioni Spes, Milazzo.

Friggieri, Oliver (ed.) (1986b): Il-Poezija Maltija. Malta, Malta University Publishers.

Friggieri, Oliver (ed.) (1993): Journal of Maltese Studies - Essays on Mikiel Anton Vassalli, 23 24, 1993.

Friggieri, Oliver (ed.) (1996): Il-Poezija Maltija. Malta, Malta University Publishers.

Friggieri, Oliver (2010): Dizzjunarju ta' Termini Letterarji. Malta, Klabb Kotba Maltin.

Friggieri, Oliver (2014): L-Istorja tal-Innu Malti. Malta, Klabb Kotba Maltin.

Hull, Geoffrey (1993): The Maltese Language Question - A Case History in Cultural Imperialism. Malta, Said International Ltd.

Laferla, Albert V. (1938): British Malta. I. Malta, Government Printing Office.

Laferla, Albert V. (1947): British Malta. II. Malta, A.C. Aquilina \& Co.

Mangion, Giovanni (1970): Governo inglese, Risorgimento italiano ed opinione pubblica a Malta (1848-1851). Malta, Casa San Giuseppe.

Marshall, David (1971): History of the Maltese Language in Local Education. Malta, Malta University Press.

Mifsud, Alfred (1917): La Cattedrale e l'Università, ossia il Comune e la Chiesa in Malta. La Diocesi II, vol. II, 7/7/1917, pp. 39-40.

Mifsud, Alfred (1918): Malta al sovrano nel 1409. La Diocesi, II, vol. VIII, 7/1/1918, pp. 243-248.

Myers, Allen C. (ed.) (1987): The Eerdmans Bible Dictionary. Michigan, William B. Eerdmans Publishing Company.

Picciotto, G. (1959): Il siciliano dialetto italiano. Orbis 3/1, pp. 25-30.

Saydon, Peter Paul (1956): Il-Kotba Mqaddsa Maqlubin u Mfissrin bil-Malti. Malta, Empire Press.

Strickland, Gerald (1921): Malta and the Phoenicians. Malta, Progress Press Co.

Vassalli, Mikiel Anton (1791): Mylsen phoenico-punicum sive grammatica melitensis. Roma, Antonio Fulgonio.

Vassalli, Mikiel Anton (1796): Ktieb il-Kliem Malti. Roma, Antonio Fulgonio.

Vassallo, Gan Anton (1895): Hrejjef u Cajt bil-Malti. Malta, Tip. Industriale G. Muscat.

Vella, Andrew (1974): Storja ta' Malta. I. Malta, Klabb Kotba Maltin.

Wettinger, Godfrey - Fsadni, Michael (1968): Peter Caxaro's Cantilena. Malta, Lux Press.

Zammit, Edward (1988): Aspects of British Colonial Policies and Maltese Patterns of Behaviour. In: Mallia Milanes, Victor (ed.): The British Colonial Experience 1800-1964. Malta, Mireva Publications, pp. 163-211. 
